\title{
INSTITUTIONAL QUALITY, TRADE OPENNESS, AND FINANCIAL DEVELOPMENT IN ASIA: AN EMPIRICAL INVESTIGATION
}

Thai-Ha Le, Jungsuk Kim, and Minsoo Lee

NO. 452

September 2015
ADB ECONOMICS WORKING PAPER SERIES 
ADB Economics Working Paper Series

\section{Institutional Quality, Trade Openness, and Financial Development in Asia: An Empirical Investigation}

Thai-Ha Le, Jungsuk Kim, and Minsoo Lee

No. 452 | September 2015
Thai-Ha Le (ha.lethai@rmit.edu.vn) is Lecturer at the Centre of Commerce and Management, RMIT University (Viet Nam Campus). Jungsuk Kim (ias7@sogang.ac.kr) is Researcher at the Institute of International and Area Studies, Sogang University. Minsoo Lee (mlee@adb.org) is Senior Economist at the Asian Development Bank. 
Asian Development Bank

6 ADB Avenue, Mandaluyong City

1550 Metro Manila, Philippines

www.adb.org

(C) 2015 by Asian Development Bank

September 2015

ISSN 2313-6537 (Print), 2313-6545 (e-ISSN)

Publication Stock No. WPS157626-2

The views expressed in this paper are those of the authors and do not necessarily reflect the views and policies of the Asian Development Bank (ADB) or its Board of Governors or the governments they represent.

ADB does not guarantee the accuracy of the data included in this publication and accepts no responsibility for any consequence of their use.

By making any designation of or reference to a particular territory or geographic area, or by using the term "country" in this document, $A D B$ does not intend to make any judgments as to the legal or other status of any territory or area.

Note: In this publication, "\$” refers to US dollars.

The ADB Economics Working Paper Series is a forum for stimulating discussion and eliciting feedback on ongoing and recently completed research and policy studies undertaken by the Asian Development Bank (ADB) staff, consultants, or resource persons. The series deals with key economic and development problems, particularly those facing the Asia and Pacific region; as well as conceptual, analytical, or methodological issues relating to project/program economic analysis, and statistical data and measurement. The series aims to enhance the knowledge on Asia's development and policy challenges; strengthen analytical rigor and quality of ADB's country partnership strategies, and its subregional and country operations; and improve the quality and availability of statistical data and development indicators for monitoring development effectiveness.

The ADB Economics Working Paper Series is a quick-disseminating, informal publication whose titles could subsequently be revised for publication as articles in professional journals or chapters in books. The series is maintained by the Economic Research and Regional Cooperation Department. 


\section{CONTENTS}

TABLES

ABSTRACT

$\begin{array}{lll}\text { I. INTRODUCTION } & 1\end{array}$

II. LITERATURE REVIEW 2

III. EMPIRICAL STRATEGY 3

A. Variables and Data 3

B. Methodology 4

$\begin{array}{ll}\text { IV. } & \text { EMPIRICALRESULTS }\end{array}$

V. CONCLUSIONS AND POLICYIMPLICATIONS

$\begin{array}{ll}\text { APPENDIX } & 13\end{array}$

$\begin{array}{ll}\text { REFERENCES } & 15\end{array}$ 


\section{TABLES}

\section{TABLES}

1. Summary Statistics and Results of Principal Component Analysis 5

2 Summary of Descriptive Statistics of the Variables 6

3 Results of Diagnostic Tests for Heteroscedasticity, Serial Correlation, and Contemporaneous Correlation 8

4 Bias-Adjusted Lagrange Multiplier Test of Error Cross-Section Independence 9

$5 \quad$ Panel Unit Root Results, 1995-2011 9

6 Results of Dynamic Panel Generalized Method of Moments Estimations

Dependent Variable: Financial Development 


\begin{abstract}
We examine the determinants of financial development in Asia and the Pacific from 1995 to 2011. To do so, we apply the dynamic generalized method of moments to a panel data set of 26 economies in the region. We find that better governance and institutional quality foster financial development in developing economies while economic growth and trade openness are key determinants of financial depth in developed economies.
\end{abstract}

Keywords: Asia and the Pacific, economic growth, financial development, governance and institutional quality, panel data analysis, trade openness

JEL Classification: G10, G20 


\section{INTRODUCTION}

It is well-established in the finance-growth literature that financial development contributes to economic growth through both direct and indirect channels. Financial deepening increases the supply of capital and facilitates the allocation of financial resources to investment and other productive activities. On a broader level, well-functioning banks and capital markets contribute to a more efficient allocation of resources as well as to innovation and other dynamic efficiency gains over time. Furthermore, the finance sector directly provides valuable, growth-promoting, real services. In particular, it helps to identify profitable business opportunities and to improve corporate governance (Levine 2005, Roubini and Sala-i-Martin 1992).

This study aims to examine the determinants of financial development in the Asia and Pacific region with a focus on institutional quality, trade openness, and economic growth. In terms of economic growth, over the last 20 years the region has outperformed other parts of the world and has also experienced major developments in its traditionally bank-dominated financial system since the 1997 Asian financial crisis. For example, bond and stock markets as well as institutional investors have become more important. Nevertheless, the role of capital markets still remains limited relative to banks. A few large companies account for most issuances of equities and bonds, and many secondary markets remain illiquid and shallow. A significant share of bond markets is accounted for by the public sector. Overall, in the global context, financial systems in the region remain less developed than those in advanced countries but more developed than those in Eastern Europe and Latin America.

The Asia and Pacific region comprises economies that are diverse in terms of financial development. Even among the region's developed economies, scores on different measures of financial development are quite different. For instance, according to the World Economic Forum's Financial Development Report, as of 2012, Hong Kong, China scored well in business environment and the size and efficiency of the banking system, but it performed relatively less well in aggregate macroeconomic indicators and in the management of its public debt. Singapore, for its part, scored well in financial stability and in addition boasted highly developed foreign exchange, derivatives, and equity markets. On the other hand, the country lacked a well-developed bond market. In addition, financial information disclosure was relatively weak. Japan enjoyed high scores for its banking and nonbanking financial services and financial markets. In contrast, its business environment and financial access were relatively weak for a developed country. The Republic of Korea performed well in financial access but poorly in institutional environment and financial stability.

The Asia and Pacific region has become the main growth driver of the global economy in recent decades. Furthermore, its share of world output is rapidly expanding, and for the foreseeable future, the region will continue to grow faster than the rest of the world. Nevertheless, it is still home to the largest number of poor people with more than $60 \%$ of the world's poor. Financial development, in particular broadening financial access, can make a substantial contribution to poverty reduction. In addition to poverty reduction, a sound and efficient financial system that allocates capital to productive investments and promotes innovation is vital for economic growth. Asia cannot take rapid growth for granted, especially in the more challenging postglobal economic crisis period when the region's growth has visibly slowed down. As such, identifying the key determinants of financial development is of great interest to Asian policy makers.

The central objective of our paper is to empirically examine the determinants of financial development in a sample of 26 countries in the Asia and Pacific region. Their financial systems play a large and growing role in the global financial system in tandem with their large and growing role in the 
world economy. We investigate whether trade openness, governance and institutional quality, and economic growth promote financial development. We contribute to the existing literature on determinants of financial development by (i) using advanced econometric methods for panel data estimations, (ii) employing a composite finance indicator in order to proxy financial development in a broad sense, and (iii) taking into account the role of governance and institutional quality in financial development, an issue that has not been studied thoroughly in the existing literature.

The second section of this paper reviews the literature on determinants of financial development. The third part presents the empirical framework and data used in this study. The fourth section reports and discusses the key findings that emerge from our analysis. The final section concludes the paper.

\section{LITERATURE REVIEW}

Our investigation of the possible determinants of financial development in the Asia and Pacific region centers on three factors: economic growth, trade openness, and governance and institutional quality. We chose these variables due to well-established theories and findings from the literature as well as data availability.

Several models have been proposed to analyze the relationship between financial development and economic growth (e.g., Levine 2005; Law and Singh 2014; Cheng, Ho, and Hou 2014; Gaffeo and Garalova 2014). The debate regarding the direction of causality between the two variables has been ongoing since the 19th century. The first view argues that financial development affects economic growth through accumulative and allocative channels. The accumulative channel refers to the finance-induced effects of physical and human capital accumulation on economic growth (e.g., Pagano 1993). Meanwhile, the allocative channel denotes finance-induced gains in resource allocation efficiency (e.g., King and Levine 1993). The second view contends that economic growth drives the development of the finance sector. For instance, when an economy is expanding, the private sector may demand new financial instruments and better access to external finance. In this regard, financial activities simply expand in step with general economic development (e.g., Robinson 1952). The third view maintains that finance and growth may be mutually dependent. An expanding real sector provides the resources that the financial system needs for its own expansion. This eventually allows for financial economies of scale that in turn facilitate further economic development (e.g., Berthelemy and Varoudakis 1996). Finally, the fourth view is more skeptical about the finance-growth nexus: Finance and growth may also evolve independently of each other, so no causality (or insignificant causation) exists between them (Chandavarkar 1992).

With regard to the link between financial development and trade openness, countries with a relatively well-developed finance sector are shown to have a comparative advantage in industries and sectors that rely on external finance (Kletzer and Bardhan 1987). Extending this argument and allowing one sector of a two-sector model to be more credit intensive due to increasing returns to scale, the level of financial development is found to affect the structure of the trade balance (Beck 2002). Reforming the finance sector might have implications for the trade balance if the level of financial development is a determinant of a country's comparative advantage. On the other hand, the effect of trade reforms on the level and structure of the trade balance might depend on the level of financial development. More recently, in building a model with two sectors, one of which is financially extensive, Do and Levchenko (2004) found that trade openness will affect the demand for external finance and thus financial depth in the trading countries. In particular, their model predicts that greater openness in 
high-income countries should be related to faster financial development. On the contrary, in lowincome countries more trade can slow financial development because they tend to import financially intensive goods, which impedes the development of their own financial systems.

While the roles of economic growth and trade openness as sources of financial development are well documented in the existing literature, studies on the link between institutional quality and financial development are relatively scarce (e.g., Levine 1997, Chinn and Ito 2006, Roe and Siegel 2007, Huang 2010). Levine (1997) admits that institutions play an important role in the performance of financial markets. For example, unstable governments cannot credibly commit to policies that can encourage and foster entrepreneurial activity, savings, and the functioning of financial markets. Furthermore, political instability will likely lead to imprudent macroeconomic policy and hence, hamper the development of financial infrastructure (Roe and Siegel 2007).

Huang (2010) also argues that political stability and institutional improvement promote the development of the finance sector. In addition, Chinn and Ito (2006) found that the relationship between trade openness and financial development was contingent on institutional quality. More specifically, increased trade openness promotes financial development only after institutional quality exceeds a certain threshold. Capasso (2004) emphasized that good institutions enable the financial markets to channel resources to productive activities and to minimize their waste and misuse. In summary, all of these arguments suggest that institutional quality could be an important foundation for financial development.

\section{EMPIRICAL STRATEGY}

\section{A. Variables and Data}

We use annual time-series data as they are sufficient to ensure the quality of the analysis (Hakkio and Rush 1991); the choice of the sample countries was subject to the availability of comprehensive data sets. The logarithm of per capita real gross domestic product (GDP) represents the level of economic growth (EG). For trade openness (TO), the logarithm of the sum of exports and imports to real GDP is used because this measure is a simple and common indicator of TO as suggested by Harrison (1996). The data were taken from the World Bank's World Development Indicators (WDI) database. A large body of literature has discussed the extent and efficiency of possible measures for the level of financial development. In the financial development literature, creating indicators to measure cross-country data is a rather complex issue. The difficulty concerns the accuracy and comparability of the crosssectional data of economies.

Several indicators for measuring financial deepening have been suggested in finance-growth literature. For instance, money aggregates such as M2 or M3 as a ratio of GDP (e.g., Odhiambo 2008) are traditional proxies for financial development; however, there have been debates on the superiority of these indicators, particularly given the availability of foreign funds in the financial system. The second popular measure of overall financial development is the ratio of liquid liabilities to GDP (LLGDP) which is based on the liquid liabilities of the financial system (King and Levine 1993). While this variable explains positive correlations between the size of the finance sector and the level of provision of financial services, it often overestimates economies with undeveloped financial markets. An additional popular proxy for financial development proposed by King and Levine (1993) is the ratio of commercial bank assets to the sum of commercial bank assets and central bank assets (DBACBA) which is used to measure the relative importance of commercial banks in the financial system. Another 
standard measure is the ratio to GDP of credit issued to the private sector by banks and other financial intermediaries (PCRDBOFGDP) which focuses solely on the claims on the private sector (Beck, Demirgüç-Kunt, and Levine 2000).

This study employs an array of variables related to financial development and follows a recent method by Ang and McKibbin (2007) to construct a composite indicator of financial deepening that is as broad as possible. Specifically, logarithms of finance proxies including LLGDP, PCRDBOFGDP, and DBACBA are used to construct this financial development (FD) index via a principal component analysis. Since most financial systems in developing Asia are bank dominated, the financial indicators that are primarily associated with bank development are considered to represent the proper level of financial deepening.

Finance-growth literature focuses on financial intermediaries (Demirgüç-Kunt and Levine 1996a, 1996b) for two reasons. First, the vast majority of financial systems in emerging and developing economies-including most in our sample-is based on central and commercial banks. Second, statistics on central and commercial banks are readily available while data on stock markets in less developed economies have been scarce until recently. In addition, Demirgüç-Kunt and Levine (1996a) also noted that countries with better-developed stock markets often have better-developed banks and non-bank financial intermediaries.

Data for the individual finance indicators are taken from the updated and expanded version of the Financial Development and Structure Database as of 2013 (Beck, Demirgüç-Kunt, and Levine 2000). The principal component analysis reduces data sets to lower dimensions while retaining as much information from the original sets as possible. This helps to deal with the problems of multicollinearity and overparameterization in modeling. In this case, the finance indicators are transformed into natural logarithms and only the first unrotated principal component is extracted as FD.

Table 1 provides an overview of the results of the principal component analysis and a descriptive overview of the countries investigated. The index used in this study is usually the only component to show fitting characteristics. The first principal component adequately explains at least $50 \%$ of the variations of the three components of the FD index for all sample countries and is better than any other linear combination of explanatory variables. Furthermore, it exhibits an eigenvalue that is significantly larger than 1 .

Another major challenge was to find an adequate indicator for the governance and institutional quality (GI). This study computed $\mathrm{Gl}$ by averaging together six dimensions of governance obtained from the World Bank's Worldwide Governance Indicators (WGI): voice and accountability, political stability and absence of violence, government effectiveness, regulatory quality, rule of law, and control of corruption. These six have high intercorrelations as they appear to measure the same broad concept (Langbein and Knack 2010). Many studies in related literature also used the same approach to obtain a single, broader index (e.g., Easterly 2002, Al-Marhubi 2004, Bjornksov 2006).

The details of the data sets are summarized in Table 2. 


\section{B. Methodology}

Based on the theoretical arguments presented above, this study specifies the following financial development relationship:

$$
F D_{i t}=\alpha_{i}+\beta \cdot F D_{i t-1}+\gamma \cdot E G_{i t}+\delta \cdot G I_{t}+\vartheta \cdot T O_{i t}+\varepsilon_{i t}
$$

Table 1: Summary Statistics and Results of Principal Component Analysis

\begin{tabular}{|c|c|c|c|c|c|}
\hline \multirow[b]{2}{*}{ Country } & \multirow{2}{*}{$\begin{array}{c}\text { First Principal } \\
\text { Component } \\
\text { (\% of variance) }\end{array}$} & \multicolumn{3}{|c|}{ Component Matrix } & \multirow[b]{2}{*}{ Eigenvalues } \\
\hline & & DBACBA & LLGDP & PCRDBOFGDP & \\
\hline Armenia & 77.19 & 0.575 & 0.634 & 0.517 & 2.316 \\
\hline Azerbaijan & 70.26 & 0.469 & 0.631 & 0.618 & 2.108 \\
\hline Bangladesh & 65.58 & 0.081 & 0.705 & 0.705 & 1.968 \\
\hline People's Republic of China & 70.90 & 0.382 & 0.630 & 0.676 & 2.127 \\
\hline Fiji & 52.33 & -0.510 & 0.391 & 0.766 & 1.570 \\
\hline Georgia & 98.76 & 0.576 & 0.578 & 0.577 & 2.963 \\
\hline Indonesia & 59.85 & 0.697 & 0.059 & 0.715 & 1.795 \\
\hline India & 95.00 & 0.567 & 0.587 & 0.578 & 2.850 \\
\hline $\begin{array}{l}\text { Cambodia } \\
\text { Lao People's Democratic }\end{array}$ & 96.31 & 0.572 & 0.586 & 0.575 & 2.889 \\
\hline Republic & 58.37 & 0.163 & 0.697 & 0.698 & 1.751 \\
\hline Sri Lanka & 54.15 & 0.705 & -0.690 & 0.160 & 1.624 \\
\hline Mongolia & 75.72 & 0.447 & 0.636 & 0.629 & 2.272 \\
\hline Malaysia & 63.47 & -0.642 & 0.338 & 0.688 & 1.904 \\
\hline Nepal & 91.72 & 0.564 & 0.601 & 0.567 & 2.752 \\
\hline Pakistan & 63.59 & 0.273 & 0.691 & 0.669 & 1.908 \\
\hline Philippines & 50.35 & -0.698 & 0.032 & 0.716 & 1.510 \\
\hline Thailand & 55.58 & 0.586 & -0.700 & 0.408 & 1.667 \\
\hline Tonga & 59.79 & 0.042 & 0.708 & 0.705 & 1.794 \\
\hline Viet Nam & 96.82 & 0.569 & 0.584 & 0.579 & 2.905 \\
\hline Vanuatu & 79.81 & 0.595 & -0.541 & 0.594 & 2.394 \\
\hline Samoa & 65.91 & -0.167 & 0.702 & 0.692 & 1.977 \\
\hline Australia & 59.06 & 0.662 & 0.728 & 0.179 & 2.090 \\
\hline Japan & 76.48 & 0.520 & 0.570 & 0.636 & 2.295 \\
\hline Republic of Korea & 80.55 & 0.015 & 0.063 & 0.998 & 0.007 \\
\hline New Zealand & 85.79 & 0.556 & 0.562 & 0.613 & 2.574 \\
\hline Singapore & 59.06 & 0.662 & 0.728 & 0.179 & 1.772 \\
\hline
\end{tabular}

DBACBA $=$ the ratio of commercial bank assets to the sum of commercial bank assets and central bank assets, LLGDP = the ratio of liquid liabilities to gross domestic product (GDP), PCRDBOFGDP = the ratio to GDP of credit issued to private sector by banks and other financial intermediaries.

Notes: Data for the individual finance indicators were taken from the updated and expanded version of Financial Development and Structure Database (Beck, Demirgüç-Kunt, and Levine 2000). The second column (first principal component) contains the value of the initial eigenvalues as a percentage of the total variance the first principal component contains (percentage of variance criterion) that represents the composite indicator of financial depth.

Source: Authors' calculations. 
We used a dynamic panel specification to allow a lagged dependent variable for the partial adjustment of FD to its long-run equilibrium value within 1 year. Since the time-series variance in financial development in modern times is significant, an empirical investigation of its determinants needs to consider its variation both across countries and over time (Baltagi, Demetriades, and Law 2009). Therefore, this study implements panel data techniques to investigate the determinants of financial development for 26 countries in the Asia and Pacific region from 1995 to 2011. In addition, in opposition to time-series and cross-sectional data, by controlling individual heterogeneity, panel data allow for more informative data, more variability, less collinearity among the variables, more degrees of freedom, and more efficiency (Baltagi 2005).

\section{Table 2: Summary of Descriptive Statistics of the Variables}

\begin{tabular}{|c|c|c|c|c|c|c|}
\hline Variable & Source & $\begin{array}{c}\text { Unit of } \\
\text { Measurement }\end{array}$ & Mean & SD & Min & Max \\
\hline GDP per capita & World Development Indicators & constant $2005 \$$ & $6,530.62$ & $10,765.5$ & 262.742 & $37,185.2$ \\
\hline $\begin{array}{l}\text { Trade openness } \\
\text { Indicators from } \\
\text { Worldwide }\end{array}$ & World Development Indicators & $\%$ of GDP & 90.469 & 68.502 & 16.750 & 439.657 \\
\hline $\begin{array}{l}\text { Governance } \\
\text { Indicators }\end{array}$ & $\begin{array}{l}\text { Worldwide Governance } \\
\text { Indicators } \\
\text { Financial Development and }\end{array}$ & $\%$ & 47.607 & 23.231 & 9.039 & 98.664 \\
\hline DBACBA & $\begin{array}{l}\text { Structure Dataset } \\
\text { Financial Development and }\end{array}$ & $\%$ & 89.853 & 12.260 & 27.507 & 99.992 \\
\hline LLGDP & $\begin{array}{l}\text { Structure Dataset } \\
\text { Financial Development and }\end{array}$ & $\%$ & 62.964 & 46.158 & 5.986 & 239.201 \\
\hline $\begin{array}{l}\text { PCRDBOFGDP } \\
\text { Financial } \\
\text { development } \\
\text { indicator }\end{array}$ & $\begin{array}{l}\text { Structure Dataset } \\
\text { Computed using principal } \\
\text { component analysis }\end{array}$ & $\%$ & 54.818 & 47.628 & -3.664 & 228.035 \\
\hline
\end{tabular}

$\mathrm{DBACBA}=$ the ratio of commercial bank assets to the sum of commercial bank assets and central bank assets, GDP = gross domestic product, LLGDP = the ratio of liquid liabilities to gross domestic product (GDP), PCRDBOFGDP = the ratio to GDP of credit issued to the private sector by banks and other financial intermediaries, $\mathrm{SD}=$ standard deviation, US = United States.

Source: Authors' calculations.

The first step in the analysis was to test cross-sectional dependence in order to decide appropriate unit root tests. Cross-sectional independence states that error terms are not crosscorrelated and that zero error covariance is a very important issue in panel unit root tests. Chang (2002) argued that the derived distributions of panel unit root tests could be invalid if this assumption is relaxed. It could be instead dependent on various nuisance parameters in a very complicated way that results in correlations across individual units. As noted in Cerrato (2001), cross-sectional dependence can be caused by different factors such as model misspecification or common shocks. Failure to take into consideration cross-sectional dependence between the series may cause significantly biased results (Breusch and Pagan 1980, Pesaran 2004).

In terms of econometrics, cross-sectional dependency could be explained as individuals forming panels are related to error terms in the panel data model as indicated in Equation (2). That is, if individuals forming a panel are affected by a shock, other individuals in the panel are affected as well.

$$
y_{i t}=\alpha_{i}+\beta_{i} x_{i t}+\varepsilon_{i t}
$$

where $\operatorname{cov}\left(\varepsilon_{i t}, \varepsilon_{i j}\right) \# 0$. 
Several Lagrange Multiplier (LM) tests are available to check cross-sectional dependence (CD), namely, $C D_{\mathrm{LM} 1}, C D_{\mathrm{LM} 1}$ adj, $C D_{\mathrm{LM} 2}$ and $C D_{\mathrm{LM}}$. The $\mathrm{CD}_{\mathrm{LM} 1}$ test was developed by Breusch and Pagan (1980), and the $C D_{L M 1}$ adj test developed by Pesaran, Ullah, and Yamagata (2008) is a modified version of the $C D_{L M 1}$ test. $A C D_{L M 1}$ test is useful when $N$ is fixed and $T$ goes to infinity. The other LM tests$C D_{L M 2}$ and $C D_{L M}$ tests - were developed by Pesaran (2004). $A C D_{L M 2}$ test is useful when $T$ and $N$ are large enough (Guloglu and Ivrendi 2008). On the other hand, $C D_{L M}$ is better to use when $N$ is larger and $T$ is smaller, which is the case in this study. As such, this study employed the $C D_{\text {LM }}$ test to check cross-sectional dependency. All $C D_{L M}$ tests come with the null hypothesis of no cross-sectional dependency across units. For the second step, panel unit root tests were conducted.

Two groups of panel unit root tests are developed in literature. The first group consists of firstgeneration unit root tests that ignore cross-sectional dependence. The second group includes secondgeneration unit root tests that take cross-sectional dependence into account (e.g., Phillips and Sul 2003, Moon and Perron 2004, Smith et al. 2004, Pesaran 2007). Pesaran (2007) introduced a framework in which he allowed $\frac{N}{T} \rightarrow \sigma$ for a positive real value. The small sample size properties of existing tests have been examined extensively. Following the approach in Pesaran (2007), this study proposes a single factor structure for the error term to tackle cross-sectional dependence, while the test statistic proposed here is based on LM.

In a cross-sectional analysis, the error variance is likely to vary across the groups impacting the consistency of the estimators. Using the generalized least squares (GLS) method in the estimation could solve this problem; however, other sources of variance variability might still exist represented by the correlation of the squared residuals with the regressors in each group. There are two sources of within-group heteroscedasticity that could be given either by differences in the unconditional variance of the residual terms or by differences in the variance of the residual terms conditioned on the regressors. For this purpose, this study uses an efficient estimator which uses the generalized method of moments (GMM) to control for both heteroscedasticity sources. The GMM system estimator ensures orthogonality between the lagged endogenous variables and the residual term. The lagged variables are used as instruments, appropriately weighted.

Consider the model

$$
Y_{i t}=\alpha+X_{i t}^{\prime} \beta+\delta_{i}+\gamma_{t}+\varepsilon_{i t}
$$

where $i=\overline{1, N}, t=\overline{1, T}, Y$ is a dependent variable, $\alpha$ is a constant, $\mathrm{X}$ is a vector of explanatory variables, $\beta$ represents a vector of coefficients to be estimated, $\varepsilon_{i t}$ represents the residual terms, $\delta_{i}$ and $\gamma_{t}$ are the cross-section and, respectively period fixed or random effects.

The GMM estimator is computed based on the following:

$$
g(\beta)=\sum_{i=1}^{M} g_{i}(\beta)=\sum_{i=1}^{M} Z_{i}^{\prime} \varepsilon_{i}(\beta)
$$


and solves the following minimization problem, function of $\beta$ :

$$
S(\beta)=\left(\sum_{i=1}^{M} Z_{i}^{\prime} \varepsilon_{i}(\beta)\right)^{\prime} W\left(\sum_{i=1}^{M} Z_{i}^{\prime} \varepsilon_{i}(\beta)\right)=g(\beta)^{\prime} W g(\beta)
$$

We first tested three different assumptions about the error process in order to explore the GMM model with the best fitted error process for the data. Contemporaneous correlation, serial correlation, and heteroscedasticity were tested, respectively, using Breusch and Pagan's LM test (1980), the Wooldridge (2002) test and the Modified Wald test as proposed by Greene (2008). The null hypotheses of the first and third tests are, respectively, that there is no contemporaneous correlation and there is homoscedasticity. The null hypothesis of the second test is that there is no serial correlation. Table 3 confirms the existence of serial correlation and heteroscedasticity at the 5\% significance level. Given the result, we employed the GMM model with an error process that assumes contemporaneous correlation, serial correlation, and heteroscedasticity (Greene 2008).

\section{Table 3: Results of Diagnostic Tests for Heteroscedasticity, Serial Correlation, and Contemporaneous Correlation}

\begin{tabular}{|c|c|c|c|c|c|}
\hline Test & Error Process & $\begin{array}{c}\text { Test } \\
\text { Statistic } \\
\end{array}$ & $\begin{array}{c}\text { All Countries } \\
\text { (1) }\end{array}$ & $\begin{array}{c}\text { Developed } \\
\text { Economies } \\
\text { (2) }\end{array}$ & $\begin{array}{c}\text { Developing } \\
\text { Economies } \\
\text { (3) }\end{array}$ \\
\hline Modified Wald test & Heteroscedasticity & Chi(2) & $1360.13^{* * *}$ & $43.74^{* * *}$ & $884.09^{* * *}$ \\
\hline $\begin{array}{l}\text { Breusch-Pagan LM } \\
\text { test }\end{array}$ & $\begin{array}{l}\text { Contemporaneous } \\
\text { correlation }\end{array}$ & Chi(2) & - & $28.145^{* * *}$ & - \\
\hline Wooldridge test & Serial correlation & & $17.009^{* * *}$ & $7.458^{* *}$ & $8.754^{* * *}$ \\
\hline
\end{tabular}

- = correlation matrix of residuals is singular; it is not possible to test, $L M=$ Lagrange Multiplier.

Notes: ${ }^{*} p<0.05,{ }^{* *} p<0.01,{ }^{* * *} p<0.001$.

Heteroscedasticity: Modified Wald test for group-wise heteroscedasticity in fixed effect regression model; $\mathrm{H}_{0}$ : sigma(i)^2 = sigma^2 for all i: No heteroscedasticity.

Serial correlation: Wooldridge test for autocorrelation in panel data; $\mathrm{H}_{0}$ : No first-order autocorrelation.

Contemporaneous correlation: Breusch-Pagan Lagrange Multiplier test; $\mathrm{H}_{0}$ : No contemporaneous correlation

Source: Authors' calculations.

In addition, desirable properties of the GMM and GMM estimators hold asymptotic for large $\mathrm{N}$, which is particularly more suitable when $\mathrm{N}>\mathrm{T}$ as in this study. Meanwhile, GLS is more suitable for samples with a small number of cross-sectional units. This gives rise to an important reason for choosing GMM as the main method in this study. 


\section{EMPIRICAL RESULTS}

In the first stage of the analysis, the study tested $C D$. Table 4 reports the results of conducting the $C D_{\text {LM }}$ test.

Table 4: Bias-Adjusted Lagrange Multiplier Test of Error Cross-section Independence

\begin{tabular}{lrc}
\hline Test & $\begin{array}{c}\text { Statistic } \\
\text { Fixed Effect }\end{array}$ & $\begin{array}{c}\text { Statistic } \\
\text { Random Effect }\end{array}$ \\
\hline LM Pesaran (2004) & $8.955^{* * *}$ & $12.719^{* * *}$ \\
LM Frees (1995) & $19.224^{* * *}$ & $18.854^{* * *}$ \\
\hline
\end{tabular}

LM = Lagrange Multiplier.

Notes: ${ }^{*} p<0.05,{ }^{* *} p<0.01,{ }^{* * *} p<0.001 ; H_{0}$ : cross-sectional independence.

Sources: Authors' calculations.

The CD test statistic strongly rejects the null hypothesis of no cross-sectional dependence; in addition, the average absolute correlation is very high. Hence, there is enough evidence suggesting the presence of cross-sectional dependence under a fixed effect specification. Baltagi (2005) also reported the results of the model using the random effect estimator. Here, the finding is the same as the case of the fixed effect estimator. Thus, the study proceeded by conducting panel unit root tests that consider cross-sectional dependence, i.e. the Pesaran (2007) test; the results are reported in Table 5. The unit root statistics reported are for the variables in level and in first difference. For the variables in level, there is not enough evidence to reject the null hypothesis of a unit root for all four variables. Meanwhile, when taking the first difference, the test rejects the null hypothesis at the $1 \%$ level for all the variables. This gives evidence of a panel unit root. It may thus conclude that all the series are nonstationary and integrated of order one.

Table 5: Panel Unit Root Results, 1995-2011

\begin{tabular}{ccc}
\hline & \multicolumn{2}{c}{ With Intercept } \\
\hline \multirow{2}{*}{ Test } & Level & 1st Difference \\
\cline { 2 - 3 } & CIPS Statistic & CIPS Statistic \\
\hline FD & -1.471 & $-2.303^{* *}$ \\
GI & -1.883 & $-2.599^{* * *}$ \\
EG & -1.975 & $-2.423^{* * *}$ \\
TO & -1.975 & $-2.423^{* * *}$ \\
\hline
\end{tabular}

CIPS = cross-sectionally augmented Im-Pesharan-Shin, EG = economic growth, $\mathrm{FD}$ = financial development, $\mathrm{Gl}$ = governance and institutions, $\mathrm{TO}=$ trade openness.

Notes: ${ }^{*} p<0.05,{ }^{* *} p<0.01,{ }^{* *} p<0.001 ; H_{0}: I(1)$.

Sources: Im, Pesaran, and Shin 2003; Authors' calculations.

Table 6 presents the empirical results of the baseline model using the dynamic panel GMM approach. The financial development proxy employed in the estimations was a composite indicator; the institutional quality measure came from WGI. The study estimated the whole panel of 26 countries as well as subpanels of the five developed (high-income) countries (Australia, Japan, the Republic of Korea, New Zealand, and Singapore) and the 21 developing (low- and middle-income) countries. 


\section{Table 6: Results of Dynamic Panel Generalized Method of Moments Estimations Dependent Variable: Financial Development}

\begin{tabular}{lccc}
\hline & $\begin{array}{c}\text { All } \\
\text { Economies }\end{array}$ & $\begin{array}{c}\text { Developed } \\
\text { Economies }\end{array}$ & $\begin{array}{c}\text { Developing } \\
\text { Economies }\end{array}$ \\
\cline { 2 - 4 } D.FD & FD & FD & FD \\
\hline \multirow{4}{*}{ GI } & $0.736^{* * *}$ & $1.239^{* * *}$ & $0.722^{* *}$ \\
& $(4.25)$ & $(4.84)$ & $(3.66)$ \\
EG & $0.219^{* *}$ & 0.00442 & $0.227^{*}$ \\
& $(2.93)$ & $(0.03)$ & $(2.26)$ \\
TO & $3.290^{* *}$ & $11.95^{* *}$ & 3.447 \\
& $(2.80)$ & $(2.93)$ & $(1.80)$ \\
& 2.433 & $9.841^{* *}$ & 2.211 \\
cons & $(1.84)$ & $(3.37)$ & $(0.90)$ \\
& $-25.36^{* *}$ & -80.71 & $-25.35^{* *}$ \\
$\mathrm{~N}$ & $(-3.55)$ & $(-1.76)$ & $(-2.96)$ \\
\hline
\end{tabular}

$D . F D=$ the first difference of the financial development variable, $\mathrm{EG}=$ economic growth, $\mathrm{FD}=$ financial development, $\mathrm{GI}$ = governance and institutions, $\mathrm{N}=$ number, $\mathrm{TO}=$ trade openness.

Notes: $t$ statistics are in parentheses. ${ }^{*} p<0.05,{ }^{* *} p<0.01$ and ${ }^{* * *} p<0.001$. Based on the results of heteroscedasticity, serial correlation, and contemporaneous correlation, dynamic panel data estimation methods used the robust, two-step generalized method of moments (GMM) system for the whole panel of 26 countries and the subpanel of 21 developing economies, and the one-step GMM system for the subpanel of developed economies.

Source: Authors' calculations.

The lagged dependent variable is statistically significant in all panel estimations, which implies that the dynamic GMM is an appropriate estimator and the empirical results can be relied upon for statistical inference. The findings indicate that institutional quality indicators improve financial development for the whole panel as well as for the subpanel of developing economies although for the developed economies, the variable was an insignificant determinant. Most developing economies have low values for institutional quality which suggests that policies that help to improve governance and institutions would significantly enhance the financial depth in the region. Real GDP per capita is a statistically significant determinant of financial development for the whole panel as well as for the subpanel of developed economies.

For the subpanel of developing economies, however, the coefficient of EG is statistically insignificant. It is noted that governance and institutional quality as well as the level of financial development in most of developing economies are relatively low. This finding is consistent with existing literature that the strength of the relationship between finance and growth might be dependent on institutional quality and on financial depth (e.g., Demetriades and Andrianova 2004, Rioja and Valev 2004). The coefficient of TO is only statistically significant and positive for the subpanel of developed economies. This finding suggests that for developed economies, policies that improve their openness to trade would strengthen the development of the finance sector. For the whole panel and the subpanel of developing economies, TO was found to be insignificant at all conventional significance levels. 
Finally, this study conducted two checks for robustness. First, based on Chinn and Ito (2006), the relationship between trade openness and financial development is contingent on institutional quality where increased openness to trade promotes financial development after institutions exceed a certain threshold. This study thus included a cross-product term between $\mathrm{TO}$ and $\mathrm{GI}$ in the baseline model to see if there was any major difference in the sign and the statistical significance of the coefficients. The results show that the coefficient of the TOxGI variable is not statistically significant at the $5 \%$ level for all the panels. Second, this study estimated all the panels using feasible generalized least square (FGLS) and regression with Driscoll-Kraay standard errors, but the results were qualitatively similar. 'As such, it may thus be concluded that the findings of this study are robust with respect to reasonable changes in the baseline model as well as to different approaches used.

\section{CONCLUSIONS AND POLICY IMPLICATIONS}

Financial development has been well established in the literature as an important source for economic growth and development; implementing policies to promote the finance sector requires an understanding of the determinants of its development. There are, however, only a few studies on this subject, particularly for the Asia and Pacific region. In particular, although the role of governance and institutional quality on financial development has attracted attention in recent years, there is little empirical evidence that supports a link between institutional quality and financial development.

This study aims to fill these gaps in the existing literature. Specifically, dynamic panel GMM estimations were applied to a sample of 26 countries in the Asia and Pacific region. The estimations were done for the whole panel as well as for subpanels of developed and developing economies. The main findings are that (i) better governance and institutional quality foster financial development in developing economies and (ii) economic growth and trade openness are key determinants of financial depth in developed economies. These findings are consistent with existing literature.

The policy implications of our findings for developed countries are quite limited. Policies to foster economic growth are important because they promote economic growth; other benefits of such policies are secondary. With respect to trade openness, developed countries are likely to be already very open to trade, but above all, they are financially highly developed, so the benefits from further financial development are limited at best. In fact, the global financial crisis which was caused in part by new, complex financial products highlighted the risk that too much finance may lead to a crisis that adversely affects growth, sometimes even beyond the short-term.

In stark contrast, our evidence for developing economies has much more significant policy implications. Their financial systems tend to be underdeveloped and well inside the global finance frontier. Therefore, the risk of too much finance is much less for them than it is for New York or London, and there is plenty of scope for financial systems to improve their basic function of allocating capital more efficiently. Our central finding for developing countries-the importance of governance and institutional quality-is intuitively plausible and sensible. Governance and institutions matter for the banks that still dominate Asia's financial systems and for capital markets, i.e. equity and bond markets.

\footnotetext{
The detailed results are not presented here to conserve space, but they are available upon request.
} 
The banking sector may suffer from poor governance that is evident in, for example, relationship banking that favors loans to cronies and relatives at the expense of purely commercial lending to more productive and hence, profitable borrowers. A stronger financial regulatory framework would help improve the governance of banks and other financial institutions in developing countries. Similarly, in the equity markets, poor governance can breed inefficient and inequitable practices such as insider trading that benefit a privileged few at the expense of other shareholders. Again, the key to improving governance is a sound and effective regulatory framework. On a broader level, our findings suggest that a key ingredient of financial development in developing countries is good governance and institutions. 


\section{APPENDIX}

\section{List of Countries in the Study Sample}

\begin{tabular}{|c|c|c|}
\hline Country & Region & Income \\
\hline Australia & High-income OECD members & High income \\
\hline Japan & High-income OECD members & High income \\
\hline Republic of Korea & High-income OECD members & High income \\
\hline New Zealand & High-income OECD members & High income \\
\hline Singapore & High-income non-OECD members & High income \\
\hline Armenia & Europe and Central Asia & Middle income \\
\hline Azerbaijan & Europe and Central Asia & Middle income \\
\hline People's Republic of China & East Asia and the Pacific & Middle income \\
\hline Fiji & East Asia and the Pacific & Middle income \\
\hline Georgia & Europe and Central Asia & Middle income \\
\hline Indonesia & East Asia and the Pacific & Middle income \\
\hline India & South Asia & Middle income \\
\hline Lao People's Democratic Republic & East Asia and the Pacific & Middle income \\
\hline Sri Lanka & South Asia & Middle income \\
\hline Mongolia & East Asia and the Pacific & Middle income \\
\hline Malaysia & East Asia and the Pacific & Middle income \\
\hline Pakistan & South Asia & Middle income \\
\hline Philippines & East Asia and the Pacific & Middle income \\
\hline Thailand & East Asia and the Pacific & Middle income \\
\hline Tonga & East Asia and the Pacific & Middle income \\
\hline Viet Nam & East Asia and the Pacific & Middle income \\
\hline Vanuatu & East Asia and the Pacific & Middle income \\
\hline Samoa & East Asia and the Pacific & Middle income \\
\hline Bangladesh & South Asia & Low income \\
\hline Cambodia & East Asia and the Pacific & Low income \\
\hline Nepal & South Asia & Low income \\
\hline
\end{tabular}

$\mathrm{OECD}=$ Organisation for Economic Co-operation and Development, $\mathrm{WB}=$ World Bank. 


\section{REFERENCES}

Al-Marhubi, F. 2004. The Determinants of Governance: A Cross-Country Analysis. Contemporary Economic Policy. 22 (3). pp. 394-406.

Ang, J. B. and W. J. McKibbin. .2007. Financial Liberalization, Financial Sector Development and Growth: Evidence from Malaysia. Journal of Development Economics. 84 (1). pp. 215-33.

Baltagi, B. H. 2005. Econometric Analysis of Panel Data. New York: John Wiley \& Sons.

Baltagi, B. H., P. Demetriades, and \& S. H. Law. 2009. Financial Development and Openness: Evidence from Panel Data. Journal of Development Economics. 89 (2). pp. 285-96.

Beck, T. 2002. Financial Development and International Trade: Is There a Link? Journal of International Economics. 57 (1). pp. 107-31.

Beck, T., A. Demirgüç-Kunt, and R. Levine. 2000. A New Database on Financial Development and Structure. World Bank Economic Review. 14 (3). pp. 597-605. (An earlier version was issued as World Bank Policy Research Working Paper No. 2146.)

Berthelemy, J. C. and A. Varoudakis. 1996. Economic Growth, Convergence Clubs, and the Role of Financial Development. Oxford Economic Papers. 48 (2). pp. 300-28.

Bjornksov, C. 2006. The Multiple Facets of Social Capital. European Journal of Political Economics. 22 (1). pp. 22-40.

Breusch, T. S. and A. R. Pagan. 1980. The Lagrange Multiplier Test and Its Applications to Model Specification Tests in Econometrics. Review of Economic Studies. 47(1). pp. 239-53.

Capasso, S. 2004. Financial Markets, Development and Economic Growth: Tales of Informal Asymmetries. Journal of Economic Surveys. 18 (3). pp. 267-92.

Cerrato, M. 2001. The Cross Sectional Dependence Puzzle. London: Department of Economics, London Guildhall University.

Chandavarkar, A. 1992. Of Finance and Development: Neglected and Unsettled Questions. World Development. 20 (1). pp. 33-42.

Chang, Y. 2002. Nonlinear IV Unit Root Tests in Panels with Cross-Sectional Dependency. Journal of Econometrics. 110 (2). pp. 261-92.

Cheng, S. Y., C. C. Ho, and H. Hou. 2014. The Finance-Growth Relationship and the Level of Country Development. Journal of Financial Services Research. 45 (1). pp. 117-40.

Chinn, M. and H. Ito. 2006. What Matters for Financial Development? Capital Controls, Institution, and Interactions. Journal of Development Economics. 81 (1). pp. 163-92. 
Demetriades, P. and O. Andrianova. 2004. Finance and Growth: What We Know and What We Need to Know? In A. Harwood, R. Litan, and M. Pomerleano, eds. Financial Markets and Development: The Crisis in Emerging Markets, pp. 159-78. Washington, DC: Brookings Institution Press.

Demirgüç-Kunt, A. and R. Levine. 1996a. Stock Market, Corporate Finance, and Economic Growth: An Overview. World Bank Economic Review. 10 (2). pp. 223-39.

1996b. Stock Market Development and Financial Intermediates: Stylized Facts. World Bank Economic Review. 10 (2). pp. 201-21.

Do, Q. T. and A. A. Levchenko. 2004. Trade and Financial Development. World Bank Working Paper No. 3347. Washington, DC: World Bank.

Easterly, W. 2002. The Cartel of Good Intensions: The Problem of Bureaucracy in Foreign Aid. Journal of Policy Reform. 5 (4). pp. 223-50.

Frees, E. W. 1995. Assessing Cross-Sectional Correlation in Panel Data. Journal of Econometrics. 69 (2). pp. 393-414.

Gaffeo E. and P. Garalova. 2014. On the Finance-Growth Nexus: Additional Evidence from Central and Eastern Europe Countries. Economic Change and Restructuring. 47 (2). pp. 89-115.

Greene, W. H. 2008. Econometric Analysis. 6th ed. Upper Saddle River, NJ: Prentice Hall.

Guloglu, B. and M. Ivrendi. 2008. Output Fluctuations: Transitory or Permanent? The Case of Latin America. Applied Economics Letters. 17 (4). pp. 381-86.

Hakkio, C. S. and M. Rush. 1991. Cointegration: How Short is the Long Run? Journal of International Money and Finance. 10 (4). pp. 571-81.

Harrison, A. 1996. Openness and Growth: A Time-Series, Cross-Country Analysis for Developing Countries. Journal of Development Economics. 48 (2). pp. 419-47.

Huang, Y. 2010. Political Institutions and Financial Development: An Empirical Study, World Development. 38 (12). pp. 1667-77.

Im, K. S., M. H. Pesaran, and Y. Shin. 2003. Testing for Unit Roots in Heterogeneous Panels. Journal of Econometrics. 115 (1). pp. 53-74.

King, R. and R. Levine. 1993. Finance and Growth: Schumpeter Might Be Right. Quarterly Journal of Economics. 108 (3).pp. 717-37.

Kletzer, K. and P. K. Bardhan. 1987. Credit Markets and Patterns of International Trade. Journal of Development Economics. 27 (1-2). pp. 57-70.

Langbein, L. and S. Knack. 2010. The Worldwide Government Indicators: Six, One, or None? Journal of Development Studies. 46 (2). pp. 350-70. 
Law, S.H. and N. Singh. 2014. Does Too Much Finance Harm Economic Growth? Journal of Banking and Finance. 41 (C). pp. 36-44.

Levine, R. 1997. Financial Development and Economic Growth: Views and Agenda. Journal of Economic Literature. 35 (2). pp. 688-726.

Levine, R. 2005. Finance and Growth: Theory, Evidence and Mechanisms. In P. Aghion and S. N. Durlauf, eds. Handbook of Economic Growth, Volume 1A, Chapter 12. Amsterdam: Elsevier B.V.

Moon, H. R. and B. Perron. 2004. Testing for a Unit Root in Panels with Dynamic Factors. Journal of Econometrics. 122 (1). pp. 81-126.

Odhiambo, N. M. 2008. Financial Depth, Savings and Economic Growth in Kenya: A Dynamic Causal Linkage. Economic Modelling, 25 (4). pp. 704-13.

Pagano, M. 1993. Financial Markets and Growth: An overview. European Economic Review. 37 (2-3). pp. 613-22.

Pesaran, M. H. 2007. A Simple Panel Unit Root Test in the Presence of Cross-Section Dependence. Journal of Applied Econometrics. 22 (2). pp. 265-312.

2004. General Diagnostic Tests for Cross Section Dependence in Panels. Cambridge Working Papers in Economics. Discussion Paper No. 1240. University of Cambridge.

Pesaran, M. H., A. Ullah., and T. Yamagata. 2008. A Bias-Adjusted LM Test of Error Cross-Section Independence. Econometrics Journal. 11 (1). 105-27.

Phillips, P. and D. Sul. 2003. Dynamic Panel Estimation and Homogeneity Testing under Cross Section Dependence. Econometrics Journal. 6 (1). pp. 217-59.

Rioja, F. and N. Valev. 2004. Does One Size Fit All? A Reexamination of the Finance and Growth Relationship. Journal of Development Economics. 74 (2). pp. 429-47.

Robinson, J. 1952. The Rate of Interest and Other Essays. London: Macmillan.

Roe, M. J. and J. I. Siegel. 2007. Political Instability and Financial Development. Harvard University Law School. Unpublished.

Roubini, N. and X. Sala-i-Martin. 1992. Financial Repression and Economic Growth, Journal of Development Economics. 39 (1). pp. 5-30.

Smith L. V., S. Leybourne, T. K. Kim, and P. Newbold. 2004. More Powerful Panel Data Unit Root Tests with an Application to Mean Reversion in Real Exchange Rates. Journal of Applied Econometrics. 19 (2). pp. 147-70.

World Bank. World Development Indicators (WDI). http://data.worldbank.org/data-catalog/world -development-indicators (accessed 25 January 2015). 
18 | References

- Worldwide Governance Indicators (WGI). http://info.worldbank.org/governance/wgi/ index.aspx\#home

World Economic Forum. The Financial Development Report 2012. New York: World Economic Forum USA, Inc.

Wooldridge, J. M. 2002. Econometric Analysis of Cross Section and Panel Data. Cambridge: MIT Press. 


\section{Institutional Quality, Trade Openness, and Financial Development in Asia: An Empirical Investigation}

The paper examines the determinants of financial development in Asia. It finds that better governance and institutional quality foster financial development in developing economies while economic growth and trade openness are key determinants of financial depth in developed economies.

\section{About the Asian Development Bank}

ADB's vision is an Asia and Pacific region free of poverty. Its mission is to help its developing member countries reduce poverty and improve the quality of life of their people. Despite the region's many successes, it remains home to the majority of the world's poor. ADB is committed to reducing poverty through inclusive economic growth, environmentally sustainable growth, and regional integration.

Based in Manila, ADB is owned by 67 members, including 48 from the region. Its main instruments for helping its developing member countries are policy dialogue, loans, equity investments, guarantees, grants, and technical assistance.

$\mathrm{ADB}$ 